\title{
Przeciwdziałanie problemom alkoholowym w świetle ustawy z 26 października 1982 r. O postępowaniu w sprawach nieletnich. Zagadnienia wybrane
}

\author{
Preventing alcohol-related problems in the light of the \\ Act of 26 October 1982 on proceedings in juvenile cases \\ Selected issues
}

\begin{abstract}
Abstrakt
Szkodliwe spożywanie alkoholu powoduje rocznie milion zgonów, z czego znaczną część jego ofiar stanowią młodzi ludzie. Co więcej szeroki zakres problemów związanych ze spożywaniem alkoholu może w sposób druzgocący wpływać nie tylko na samych nieletnich, ale także na ich rodziny, a nawet życie społeczności lokalnej. Wszystko to przyczyniło się do opracowania szeregu strategii zapobiegawczych lub powodujących co najmniej częściową redukcję tego zjawiska. Celem niniejszego opracowania jest przedstawienie wybranych działań podejmowanych $w$ tej dziedzinie przez sąd dla nieletnich na podstawie ustawy z dnia 26 października 1982 r. o postępowaniu w sprawach nieletnich. Oparcie obowiązującego polskiego systemu postępowania z nieletnimi na modelu opiekuńczo-wychowawczo-ochronnym i uznaniu za jego naczelną dyrektywę kierowanie się przede wszystkim dobrem nieletniego oznacza $z$ jednej strony rezygnację $z$ represji jako podstawowego środka stosowanego wobec nieletnich, a $z$ drugiej nawiązuje do zasady dobra dziecka. Wskazany priorytet dobra nieletniego, który uznany został za fundamentalną dyrektywę polskiego modelu postępowania $z$ tą grupą osób, w założeniu teoretycznym powinien rzutować na wszystkie przyjęte w nim rozwiązania prawne, a w konsekwencji także na decyzje wydawane na każdym jego etapie. Przy czym te z nich, które nie służyłyby dobru nieletniego, rozumianemu jako dążenie do osiągnięcia takich korzystnych zmian w jego osobowości i zachowaniu, aby mógł on stosownie do biologicznego wieku i dojrzałości odpowiednio funkcjonować w otaczającej go rzeczywistości społecznej, są z założenia błędne i powinny ulec zmianie lub uchyleniu. Odnosi się to także do specjalnych środków prawnych, które mają zapobiegać alkoholizmowi wśród nieletnich.
\end{abstract}

Słowa kluczowe: nieletni, uzależnienie, alkohol, demoralizacja, środki zapobiegawcze

\section{Wprowadzenie}

Alkoholizm nieletniego to sytuacja kryzysowa w życiu nie tylko dziecka, ale także jego rodziny. Problemy związane z alkoholem ma nie tylko ten, kto pije, albowiem nie funkcjonuje on w próżni społecznej. Przeciwnie - mają je wszyscy ci, którzy pozostają w bliskiej więzi z uzależnionym; ci, którzy go kochają i chcą o niego dbać, którzy żyją z nim w jakiejkolwiek wspólnocie (Sztander, 1993, s. 1). 
Tym niemniej jednak najczęstsze reakcje rodziców na ten problem to niedowierzanie, gniew, poczucie winy, a często również zaprzeczenie. Różne dane empiryczne prowadzone od połowy lat dziewięćdziesiątych ubiegłego stulecia wskazywały, że już wówczas zdecydowana większość osób (według niektórych statystyk nawet do $98 \%$ populacji) przed ukończeniem 20 . roku życia miała za sobą doświadczenia z piciem alkoholu (szerzej na ten temat: np. Siellawa-Kolbowska, 2000 , s. 307-313). Ponadto od lat systematycznie obniża się także wiek świadomej inicjacji alkoholowej, który niekiedy określany jest jako przypadający nawet na pierwsze klasy szkoły podstawowej. Co oczywiste, istnieje wiele czynników sprzyjających sięganiu przez młodych ludzi po napoje alkoholowe właśnie w wieku dorastania. Wśród nich wymienia się przede wszystkim te o charakterze genetycznym. Należy jedynie krótko przypomnieć, że uwarunkowania genetyczne alkoholizmu są od dłuższego czasu badane przez naukowców na całym świecie. Wynika z nich m.in., że zarówno u kobiet jak i u mężczyzn nawet 50-60\% ryzyka alkoholizmu może być właśnie zdeterminowane genetycznie (np. Heath i in., 1997, s. 1381-1396; zob. także Samochowiec, Fiszer-Piosik i Horodnicki, 1998, s. 179-191). To z kolei oznacza, że np. alkoholizm rodzica lub bliskiego krewnego wpływa na biologiczną podatność dziecka na doświadczenie problemów alkoholowych w przyszłości (np. Cierpiałkowska i Grzegorzewska, 2016, s. 360). Nie oznacza to jednak, że wszystkie dzieci alkoholików same zaczynają pić, czy też zostają w przyszłości partnerem/ką osoby uzależnionej. Zatem poszukiwanie przyczynowego wyjaśnienia alkoholizmu dziecka jedynie w jego kodzie genetycznym może niekiedy okazać się niewystarczające, albowiem zachowania dotyczące picia alkoholu odzwierciedlają skomplikowane oddziaływanie zarówno pomiędzy czynnikami dziedziczonymi, jak i środowiskowymi (Nieletnie picie). Jeśli bowiem rozwój psychofizyczny dziecka zachodzi w środowisku, w którym brakuje właściwych standardów (kulturowych, religijnych, innych), odpowiednich postaw wychowawczych rodziców, ich bliskości i wsparcia, to w konsekwencji także prowadzić to może do jego społecznego nieprzystosowania. W rezultacie często oznacza to powielanie negatywnych wzorców rodzinnych, a nawet podejmowanie zachowań sprzecznych z prawem lub zasadami współżycia społecznego (Ciosek, 2011, s. 277). W tym kontekście mówi się niekiedy o młodzieży z ryzykiem tzw. społecznego dziedziczenia statusu i problemów społecznych swoich rodziców czy w szerszym ujęciu o zjawisku dziedziczenia marginalizacji (ekskluzji społecznej) przez dzieci (Kalinowski, 2010, https://liberte.pl/przejawy-wykluczenia-spolecznego/; data dostępu: 11.05.2019). Innymi słowy - rodziny takie, zamiast być miejscem wsparcia dla dorastających w nich istot, stanowią podstawowe źródło problemów i zagrożeń (szerzej na ten temat np. Biernat, 2015, s. 15-34). Warto jednak zwrócić uwagę, że zdecydowana większość młodzieży wywodzi się z rodzin funkcjonujących prawidłowo, tzn. takich, w których np. brak jest uzależnienia choćby jednego z rodziców, stosowania przemocy czy pobytu w zakładach karnych. W tym obszarze do przyczyn uzależnienia od alkoholu dziecka zaliczyć można choćby wpływ grupy rówieśniczej. Sięganie po różnego rodzaju używki, w tym alkohol, staje się często głównym sposobem spędzania wolnego czasu, daje też młodym ludziom poczucie pewnej wspólnoty doświadczeń, a w skrajnych przypadkach jest nawet swego rodzaju wyznacznikiem przynależności 
do określonego środowiska. Wreszcie wskazać należy, że w przedmiotowej kwestii identyfikowane są również inne czynniki ryzyka, takie jak np. wpływ mediów, w których alkohol jest szeroko promowany, ale także przeciążenie dziecka dodatkowymi obowiązkami, związany z tym stres, z którym nie umie sobie poradzić, brak swego rodzaju „ciekawości świata” czy niestabilna samoocena - zwłaszcza w okresie adolescencji (szerzej na ten temat np. Bartosik [red.], 2003, s. 45-63).

Ustawodawca polski kwestię alkoholu i problemów z nim związanych także wśród dzieci i młodzieży traktuje priorytetowo, ale również wielopłaszczyznowo. Tym samym budzi ona zainteresowanie przedstawicieli różnych dyscyplin naukowych, wśród których zdecydowany prym wiodą nauki medyczne i społeczne. W zdecydowanie skromniejszym wymiarze problematyka ta stanowi przedmiot zainteresowania przedstawicieli nauk prawnych (np. pierwszym opracowaniem analitycznym ujmującym administracyjnoprawne aspekty problematyki alkoholowej była praca: Jaworska-Dębska, 1995, s. 1-220). Trzon modelu polskiej regulacji alkoholowej stanowi, co oczywiste, ustawa z dnia 26 października 1982 r. o wychowaniu w trzeźwości i przeciwdziałaniu alkoholizmowi (Dz.U. z 1982 r. Nr 35, poz. 230 ze zm.; dalej jako u.w.t.p.a.). Leczenie osób uzależnionych, także na gruncie tego aktu prawnego, jest co do zasady dobrowolne, a przymus leczenia może być nałożony wyłącznie przez sąd w przypadkach wskazanych w art. 24 w zw. z art. 26 ust. 1. Ustawa ta w zakresie stosowanych środków nie różnicuje ich adresatów. To oznacza, że mogą być zastosowane teoretycznie zarówno do osoby dorosłej, jak i dziecka, o ile to ostatnie spełnia przesłanki do ich zastosowania (np. w związku z nadużywaniem alkoholu systematycznie zakłóca spokój lub porządek publiczny). W nauce słusznie jednak podkreśla się, że specyfika podmiotu, jakim jest dziecko, powoduje, że oddziaływanie prawa na tę jednostkę jest szczególnie utrudnione, albowiem jego niedostatecznie ukształtowana osobowość

charakteryzuje się mniejszym poziomem integracji czynności umysłowych, mniejszą autonomizacją procesów poznawczych, również w zakresie opisywania i wartościowania obrazu świata i własnej osoby, oraz uboższym zasobem doświadczenia. Niedojrzałość psychiczna pozostaje w tym przypadku w ścisłym związku z odmiennością w zakresie roli społecznej i innym od osoby dorosłej charakterem uczestnictwa w życiu społecznym (Muszyńska, 2004, s. 56).

Dostrzeżenie owych odrębności rozwojowych dzieci i młodzieży, ich niedojrzałej osobowości, w tym ograniczonej zdolności rozumienia znaczenia dokonywanych czynów, przyniosły zapoczątkowane już pod koniec XIX w. zasadnicze zmiany w postrzeganiu i ocenianiu zachowań nagannych nieletnich oraz postępowaniu z nimi, które ukierunkowane było nie na karanie, ale na wychowanie i zmianę zachowania. Co równie istotne, zwrócono uwagę na przyczyny negatywnych zachowań nieletnich, które najczęściej tkwiły w ich środowisku wychowawczym, w warunkach, w jakich przyszło im żyć, nie zaś w nich samych (Konarska-Wrzosek, 2013, s. 40). Wszystko to doprowadziło z czasem do stworzenia - także w warunkach polskich - specjalnych środków prawnych, które byłyby skuteczne wobec tej kategorii osób, przy czym ich skuteczność rozumie się jako zapewnienie ochrony i wychowania nieletnich, którzy „zeszli na złą drogę”. 
Co za tym idzie, zaczęto tworzyć także osobne, wyspecjalizowane sądy dla nieletnich, w których jedną z zasad postępowania sądowego było wyłączenie jawności oraz odformalizowana procedura (Konarska-Wrzosek, 2013, s. 40-41).

Istotnym krokiem zmierzającym w kierunku szczególnego uregulowania problematyki antyalkoholowej wśród najmłodszych członków naszego społeczeństwa było bez wątpienia wprowadzenie w życie postanowień ustawy z dnia 26 października 1982 r. o postępowaniu w sprawach nieletnich (Dz.U z 1982 r. Nr 35, poz. 228 ze zm.; dalej jako u.p.n.). Wraz z jej uchwaleniem bowiem doszło do wyodrębnienia tzw. prawa nieletnich, obejmującego całokształt materialnoprawnych i procesowych rozwiązań ukierunkowanych na kwestie profilaktyki w postaci zapobiegania przestępczości i demoralizacji dzieci i młodzieży, ich ewentualnej resocjalizacji, ale także przewidującego środki prawne służące umacnianiu funkcji opiekuńczo-wychowawczej i poczucia odpowiedzialności rodzin za wychowanie nieletnich. Brak miejsca nie pozwala na przedstawienie różnorodności koncepcji wysuwanych jeszcze w toku prac legislacyjnych nad powołanym aktem prawnym (szerzej na ten temat: Wilkowska-Płóciennik, 2011, s. 13-16). Warto jednak zwrócić uwagę, że ostatecznie oparto go na modelu opiekuńczo-wychowawczo-ochronnym, w którym represja nie stanowi celu samego w sobie. W doktrynie nie brakuje jednak głosów, że przyjęty w 1982 r. model postępowania z nieletnimi jest niekonsekwentny, gdyż pojawiają się w nim również elementy charakterystyczne dla modelu jurydycznego (represyjnego), zwłaszcza możliwość pociągnięcia pewnej części starszych nieletnich do stricte odpowiedzialności karnej na podstawie art. 10 § 2 kodeksu karnego (Ustawa z dnia 6 czerwca 1997 r. - Kodeks karny, Dz.U. z 1997 r. Nr 88, poz. 553 ze zm.; dalej jako k.k.).Oznacza to z kolei, że nieletni warunkowo jest osobą zdolną do ponoszenia odpowiedzialności karnej za swoje czyny (Marek, 2007-2008, s. 383-391). Ta ostatnia sytuacja, podobnie jak okoliczność popełnienia przez nieletniego przestępstwa po ukończeniu 17 lat, który stanowi dolną granicę odpowiedzialności karnej (art. 10 § 1 k.k.), pozostaje jednak poza zakresem zainteresowania u.p.n.

Skoro - jak wskazano - ustawa z 1982 r. od ponad 35 lat całościowo porządkuje i systematyzuje materię dotyczącą spraw nieletnich, to tym samym powstaje pytanie o przydatność określonych w niej regulacji do oddziaływania na szeroko rozumiane problemy związane z alkoholem, a identyfikowane właśnie w obszarze zachowań najmłodszych członków społeczeństwa.

Zasadniczym celem niniejszego opracowania jest zatem określenie miejsca, jakie środki z u.p.n. zajmują w polskich regulacjach alkoholowych i ustalenie roli, jaką prawodawca mu w nich wyznaczył. W tym kontekście założeniem wyjściowym dla przyszłych rozważań jest ustalenie obszaru zachowań, które stanowić mogą podstawę do wszczęcia postępowania na podstawie tego aktu prawnego oraz ewentualnego zastosowania przewidzianych tam środków związanych z interwencją ustawodawcy w pewne formy spożycia alkoholu jako przejawu patologii społecznej. W tym zakresie dokonana zostanie analiza aktów prawnych i dorobku doktryny, a szczątkowo również orzecznictwa. Już na wstępie zastrzec należy, że mimo rozległości i wielogałęziowego wymiaru problematyki alkoholowej wśród nieletnich skutkującego pokusą zajęcia się wieloma interesującymi, choć pobocznymi, zagadnieniami, ze względu na zakres przedmiotowy 
opracowania - poniższe uwagi koncentrować się będą wokół wybranych zagadnień związanych z podjętym tematem badawczym. W konsekwencji takiego podejścia do sprawy o wielu kwestiach szczegółowych w ogóle nie będzie mowy (np. dopuszczalności stosowania wobec nieletnich sprawców środków zabezpieczających przewidzianych w k.k.), natomiast o niektórych tylko krótko. Na koniec wskazać należy, że choć niniejsze opracowanie nie aspiruje do rangi wyczerpującego przedstawienia tytułowej problematyki, to niewątpliwie służyć może jako jeden z głosów w dyskursie naukowym.

\section{Charakterystyka podstaw wszczęcia postępowania w sprawie nieletniego na podstawie u.p.n.}

Polski model decydowania o sprawach nieletnich oparty został na dwóch podstawach podjęcia działań w sprawie nieletniego: 1) wykazywaniu przejawów demoralizacji lub 2) dopuszczeniu się przez niego czynu karalnego (art. 2 u.p.n.). W konsekwencji zaistnienie każdej z tych podstaw lub obydwu łącznie powoduje, że sąd rodzinny zobligowany jest do rozważenia możliwości wszczęcia postępowania w sprawie nieletniego (art. 21 § 1 u.p.n.). Przy czym wskazać należy, że przepisy u.p.n. znajdują zastosowanie w zakresie zapobiegania i zwalczania demoralizacji tylko tych osób, które nie ukończyły 18 lat, natomiast w sprawach o czyny karalne - których dopuściły się osoby po ukończeniu 13 lat, a przed ukończeniem lat 17 (art. 1 § 1 pkt 1 i 2 u.p.n.). Ponadto w zakresie postępowania wykonawczego w stosunku do wykonywania środków wychowawczych oraz poprawczych nieletnim jest osoba, względem której te środki zostały orzeczone, choćby ukończyła lat 18, jednakże nie dłużej niż do ukończenia lat 21 (art. $1 \S 1$ pkt 3 u.p.n.). O ile pojęcie czynu karalnego nie budzi poważniejszych wątpliwości interpretacyjnych, albowiem obejmuje ono swym zakresem czyny zabronione przez ustawę jako przestępstwa, przestępstwa skarbowe i niektóre ściśle określone wykroczenia wskazane w art. $1 \S 2$ pkt 2 lit. b u.p.n, o tyle ustawa nie definiuje terminu „demoralizacja”. W literaturze słusznie wskazuje się więc na szerokie spektrum zjawisk określanych mianem demoralizacji, przy czym w art. 4 § 1 u.p.n. wymienia się jedynie przykładowo typowe jej przejawy. W. Klaus określa ten zabieg mianem „definicji przez egzemplifikację” (Klaus, 2009, s. 101), co w konsekwencji czyni naturę tego problemu skomplikowaną i niejednoznaczną, a przez to rodzić może pokusę do „dowolnego manipulowania tym pojęciem" (Górecki i Stachowiak, 2010, s. 18) choćby poprzez stosowanie w tym zakresie pewnych uproszczeń. Z uwagi na fakt, że ujęcie demoralizacji wskazane w przepisach u.p.n. jest niewystarczające, w doktrynie sformułowano wiele jej definicji. I tak np. według jednej z nich jest to „odrzucenie lub nieprzestrzeganie podstawowych norm moralnych rzutujących na wypełnianie ról społecznie ważnych, odmowę podporządkowania się uzasadnionym wymaganiom rodziny, szkoły, pracodawcy" (Strzembosz, 1983, s. 4). Według innej demoralizacja to „psycho-społeczny proces cechujący się niekorzystnymi zmianami osobowości 
i zachowań nieletniego o charakterze nasilonym i względnie trwałym, który przejawia się w nieprzestrzeganiu norm i zasad postępowania obowiązujących powszechnie dzieci i młodzież" (Górecki i Konarska-Wrzosek, 2015, s. 40). W ujęciu ogólnym demoralizacja jest także ujmowana jako szczególna postać nieprzystosowania społecznego (Bojarski i Skrętowicz, 2007, s. 43 i przywołana tam literatura). Wreszcie w świetle poglądów nauk pedagogicznych demoralizacja oznacza pewien specyficzny układ postaw i nastawień ściśle ze sobą powiązanych, które charakteryzuje nieprzestrzeganie podstawowych norm moralnych i społecznych (Sienkiewicz, 1986, s. 20).

Kontrowersje wokół pojęcia demoralizacji na gruncie u.p.n. łagodzić może preambuła wyrażająca przewodnie idee (cele) tej ustawy, a których realizacja powinna łączyć wszystkie organy oraz inne podmioty stosujące jej przepisy (Korcyl-Wolska, 2008, s. 54; Górecki i Stachowiak, 2010, s. 21-22). O ile prawna wartość takiego wstępu może być kwestią dyskusyjną, gdyż trudno jest stworzyć na podstawie samej preambuły normy prawne generalne i abstrakcyjne, o tyle nie ulega wątpliwości, że dostarcza wskazówek co do zasad interpretacji poszczególnych artykułów ustawy, w tym np. kwestii definicji demoralizacji. To oznacza, że w razie wątpliwości interpretacyjnych w zakresie tego, co było intencją ustawodawcy regulującego daną kwestię, należy odwołać się właśnie do celów u.p.n., albowiem te ostatnie mają charakter zasadniczy, a tym samym mają znaczenie dla prawidłowego rozumienia i stosowania przyjętych w ustawie rozwiązań. Ze wskazanymi celami bowiem - jak pisze V. Konarska-Wrzosek - w zgodzie pozostawać muszą zarówno wszystkie regulacje materialne, jak i procesowe zawarte w omawianej ustawie (Konarska-Wrzosek, 2013, s. 50). Zatem według preambuły do zasadniczych celów ustawy zalicza się: 1) dążenie do przeciwdziałania demoralizacji i przestępczości nieletnich; 2) stwarzanie nieletnim, którzy popadli w konflikt z prawem bądź zasadami współżycia społecznego, warunków powrotu do normalnego życia; 3) dążenie do umacniania funkcji opiekuńczo-wychowawczej i poczucia odpowiedzialności rodzin za wychowanie nieletnich na świadomych swych obowiązków członków społeczeństwa.

Największe znaczenie z punktu widzenia omawianego zagadnienia ma pierwszy z nich, który krótko określić można jako przeciwdziałanie demoralizacji i przestępczości nieletnich. W uzasadnieniu projektu u.p.n. czytamy m.in., że „[...] ustawa zajmuje się tą częścią młodzieży, która z różnych przyczyn znalazła się na marginesie społecznym. Z tego powodu ma na celu przede wszystkim zwiększenie efektywności działań zapobiegawczych oraz resocjalizacyjnych podejmowanych przez sądy rodzinne, przy jednoczesnym zwiększeniu czynnika społecznego" (Projekt ustawy o postępowaniu w sprawach nieletnich, 1982, s. 2-3). Mimo że ustawa wyraźnie wskazuje w tym zakresie na cel profilaktyczny (przeciwdziałanie demoralizacji i przestępczości nieletnich), warto jednak zwrócić uwagę na treść wspomnianego art. 2 oraz na art. $4 \S 1$ u.p.n. Przypomnijmy, że zgodnie z pierwszym z nich: „Przewidziane w ustawie działania podejmuje się w wypadkach, gdy nieletni wykazuje przejawy demoralizacji lub dopuści się czynu karalnego". Drugi z kolei nakłada społeczny obowiązek przeciwdziałania demoralizacji (m.in. poprzez zawiadomienie sądu rodzinnego i w następstwie wszczęcie postępowania przewidzianego w omawianej ustawie, ale także np. poprzez 
podjęcie niezbędnych działań ,jedynie” przez samych rodziców, opiekuna nieletniego, szkoły, do której uczęszcza, lub innej instytucji, z którą jest związany), gdy stwierdzi się istnienie okoliczności świadczących o demoralizacji nieletniego. Jak trafnie wskazuje A. Strzembosz, powyższe oznacza, że nie wystarczy do uruchomienia postępowania regulowanego przepisami tej ustawy samo zagrożenie demoralizacją, jeżeli nieletni nie ujawnia jeszcze demoralizacji, choćby nawet w niewielkim zakresie (Strzembosz, 1983, s. 12-14). W konsekwencji na gruncie u.p.n. nie sposób mówić o „czystych” środkach profilaktycznych, albowiem ustawodawca, mówiąc o przeciwdziałaniu, ma na myśli zarówno zapobieganie demoralizacji i przestępczości nieletnich, jak i ich zwalczanie, przy czym zapobieganie zachodzi wówczas, gdy w zachowaniu nieletniego pojawiają się już pierwsze niekorzystne symptomy, które sygnalizują zagrożenie demoralizacją i przestępczością lub rozpoczynający się proces jego demoralizacji. Wówczas celem jest niedopuszczenie lub powstrzymanie demoralizacji, w tym demoralizacji przestępczej. Z kolei zwalczanie demoralizacji lub przestępczości ma miejsce wówczas, gdy tego typu stany lub procesy mają już miejsce, tzn. są zaawansowane w mniejszym lub większym stopniu. Tu celem jest podejmowanie działań, które zmierzają do zatrzymania procesu pogłębiania się tych niekorzystnych zjawisk, a w najlepszym wypadku do ich całkowitego wyeliminowania (Konarska-Wrzosek, 2013, s. 63-64). W tym kontekście można powiedzieć, że na gruncie u.p.n. zapobieganie oznacza przeciwdziałanie dalszemu demoralizowaniu się nieletniego, zaś zwalczanie - usuwanie demoralizacji, czyli swoiste resocjalizowanie nieletniego, bo polegające na przyswojeniu przez nieletniego określonego sytemu norm moralnych (Strzembosz, 1983, s. 16).

Jak wskazano, w u.p.n. nie zawarto jednoznacznej definicji demoralizacji, choć w art. 4 § 1 wymienione zostały przez ustawodawcę typowe przykładowe przejawy demoralizacji nieletniego. Są nimi m.in. naruszanie zasad współżycia społecznego, systematyczne uchylanie się od obowiązku szkolnego lub kształcenia zawodowego, popełnienie czynu zabronionego, uprawianie nierządu, włóczęgostwo, a także używanie alkoholu, w tym również w celu wprowadzenia się w stan odurzenia. Jak się wydaje, za nietrafny uznać należy pogląd A. Grześkowiak, zgodnie z którym każdy przejaw demoralizacji oznacza niekorzystne zmiany osobowościowe, których rezultatem są różnorodne objawy polegające na zachowaniach sprzecznych z zasadami współżycia społecznego (Grześkowiak, 1984, s. 238 i n.). Zasady te dotyczą bowiem zachowań oburzających, społecznie nieakceptowanych, ale podejmowanych w obecności innych osób lub względem nich (Konarska-Wrzosek, 2013, s. 56). Tymczasem używanie przez nieletniego alkoholu wcale nie musi odbywać się przy lub z udziałem innych podmiotów. Ponadto sam ustawodawca wyraźnie odróżnił od siebie te kategorie zachowań. Nie ulega natomiast wątpliwości, że aby określone zachowanie naganne uznać za przejaw demoralizacji, powinno mieć ono także charakter względnie trwały (wyjątek stanowi tutaj przejaw w postaci popełnienia czynu zabronionego; Konarska-Wrzosek, 2013, s. 58), a zatem nie chodzi tutaj o przypadkowe zapalenie papierosa czy napicie się alkoholu, lecz o zachowania powtarzające się, wskazujące jednocześnie na nieprzystosowanie społeczne, objawiające się zespołem zachowań sprzecznych z podstawowymi normami moralnymi (Grzegorczyk, 1988, s. 5, 14-15; zob. 
także wyrok Sądu Apelacyjnego w Katowicach z dnia 18 marca 2004, sygn. akt II Aka 531/03, LEX nr 142829). Jeśli zatem używanie przez nieletniego alkoholu ma charakter sporadyczny, związany z nabywaniem pewnych życiowych doświadczeń, to nie stanowi przejawu demoralizacji. Dopiero gdy wykracza poza te granice, może świadczyć o demoralizacji nieletniego. Natomiast jeśli używanie alkoholu ukierunkowane jest na spowodowanie stanu odurzenia i ma miejsce częściej, daje to podstawy to uznania zachowań nieletniego za przejaw zdemoralizowania, który wymagać będzie szybkiej ingerencji w jego życie (Konarska-Wrzosek, 2013, s. 57), czyli zastosowania instrumentów prawnych (środków) przewidzianych w u.p.n.

\section{Wybrane środki prawne stosowane w sprawie nieletniego dotkniętego problemem alkoholowym}

Przechodząc do omówienia wybranych środków prawnych, które mogą znaleźć zastosowanie w postępowaniu z nieletnimi dotkniętymi problemem alkoholowym, w pierwszej kolejności jeszcze raz podkreślić należy specyfikę głównego adresata norm ustawy z 1982 r., w tym na jego nie w pełni ukształtowaną osobowość. Wszystko to, jak zauważono, rzutuje na całościowy charakter tej regulacji prawnej. Oparcie obowiązującego polskiego systemu postępowania z nieletnimi na modelu opiekuńczo-wychowawczo-ochronnym oraz uznanie za jego naczelną dyrektywę kierowanie się przede wszystkim dobrem nieletniego, oznacza z jednej strony wspomnianą rezygnację z represji jako podstawowego środka stosowanego wobec nieletnich, a z drugiej nawiązuje do zasady dobra dziecka. Ta ostatnia swoje główne źródło czerpie z kolei z art. 72 Konstytucji RP (Ustawa z dnia 2 kwietnia 1997 r. Konstytucja Rzeczypospolitej Polskiej, Dz.U. Nr 78, poz. 483 ze zm.), choć co oczywiste wykracza także poza porządek prawa krajowego (szerzej na ten temat: Łakoma, 2004, s. 93-94; Safjan, 1994, s. 267-269; Konarska-Wrzosek, 2013, s. 21-28, 230-248). Jedynie na marginesie przypomnieć wypada, że to właśnie akcentowanie w kolejnych aktach prawnych o zasięgu międzynarodowym idei dobra dziecka jako wartości nadrzędnej przyczyniło się znacząco do rozpowszechnienia świadomości dotyczącej wspomnianych odrębności rozwojowych charakteryzujących najmłodszych członków naszego społeczeństwa. To z kolei wiązało się z koniecznością ustalenia odmiennych sposobów traktowania dzieci i młodzieży w poszczególnych sfera życia społecznego, w tym w sytuacjach trudnych, często związanych z naruszeniem przez nich prawa (Konarska-Wrzosek, 2013, s. 28). O czym była już mowa, wyrazem wspomnianej tendencji stało się m.in. przyjęcie wobec nieletnich odmiennych dyrektyw i sposobów postępowania z nimi w sytuacjach objętych zakresem przedmiotowego działania u.p.n. (art. $1 \S 1$ ), a także różnorodność środków przewidzianych wobec nieletnich, w tym możliwość zasadniczo swobodnego dokonywania przez sąd rodzinny wyboru między nimi w dążeniu do osiągnięcia zamierzonego celu wychowawczego. Ponadto wspomnieć należy o konieczności dostosowaniu metod 
oddziaływania do indywidualnych potrzeb konkretnego nieletniego, która skutkować może nawet łącznym (kumulatywnym) stosowaniem określonych środków. Przede wszystkim jednak podporządkowanie polskiego modelu postępowania dominującej dyrektywie kierowania się dobrem nieletniego oznacza, że w założeniu teoretycznym powinna ona rzutować na wszystkie przyjęte w nim rozwiązania prawne, a w konsekwencji także na decyzje wydawane na każdym jego etapie, w tym decyzje dotyczące rodzaju zastosowanego środka. To oznacza również, że te z nich, które nie służyłyby dobru nieletniego, są z założenia błędne i powinny ulec zmianie lub uchyleniu (Strzembosz, 1983, s. 46).

Trzeba również pamiętać, że choć polski system prawny przewiduje kilka sytuacji dotyczących stosowania obowiązku (przymusu) leczenia, to najczęściej dotyczy to różnego rodzaju uzależnień. Wówczas pacjent często sam nie potrafi podjąć decyzji o leczeniu i potrzebna jest pomoc organów, instytucji (np. art. 26 u.w.t.p.a). W literaturze spotyka się też pogląd, że zamiast stosować określenie „przymus leczenia” lepiej jest posługiwać się pojęciem „leczenie niedobrowolne”, jako przeciwieństwem „leczenia dobrowolnego”. Wśród rodzajów leczenia niedobrowolnego na gruncie polskiego porządku prawnego wymienia się: 1) leczenie niedobrowolne niezależnie od faktu popełnienia przestępstwa lub czynu karalnego (art. 26 u.w.t.p.a.), 2) leczenie niedobrowolne osób przebywających w zakładach karnych, aresztach śledczych (art. 117 ustawy z dnia 6 czerwca 1997 r. Kodeks karny wykonawczy, Dz.U. z 1997 r. Nr 90, poz. 557 ze zm.) oraz 3) leczenie niedobrowolne jako skutek orzeczenia środka zabezpieczającego o charakterze leczniczym w związku ze skazaniem za popełnienie przestępstwa (art. 93 a k.k.) albo 4) w związku z zastosowaniem środków przewidzianych w u.p.n. (art. 12) (Fiutak, 2016, s. 760). Nie oznacza to jednak, że zasada dobrowolności poddania się leczeniu i rehabilitacji nie odnosi się do nieletnich uzależnionych od alkoholu. Zarówno nieletni, jak i jego rodzice, mogą bowiem wystąpić o leczenie i rehabilitację, jeżeli dotknięty nałogiem zamierza się poddać takiemu postępowaniu. Niemniej jednak stosowanie przymusowego leczenia wobec nieletnich z problemem alkoholowym, zarówno na gruncie u.w.t.p.a, jak i u.p.n. - w przeciwieństwie do postępowania wobec dorosłych alkoholików - stanowi pewną regułę, którą można stosować w różnych stanach faktycznych (podobnie na gruncie zjawiska narkomanii: Muszyńska, 2004, s. 55).

Jak wynika z dotychczasowych uwag, zgodnie z art. 4 § 1 u.p.n. w przypadku szkodliwego używania alkoholu przez nieletniego podstawą ewentualnej interwencji sądu rodzinnego jest „używanie alkoholu w celu wprowadzenia się w stan odurzenia". W konsekwencji użyte sformułowanie pozwala objąć swym zakresem zarówno nieletnich dopiero zagrożonych uzależnieniem alkoholowym, jak i nieletnich już uzależnionych od alkoholu. Mimo że jednym z przejawów demoralizacji, chociaż nie zawsze przesądzającym in concreto o demoralizacji nieletniego, jest zarówno używanie przez niego alkoholu, jak i w skrajnej postaci jego alkoholizm, to nie oznacza jednak, że postępowanie wobec każdej z tych kategorii podmiotów przebiega w sposób podobny. Nieletni wykazujący przejawy demoralizacji z powodu używania alkoholu objęty jest ochroną, a także pomocą w postaci leczenia, z wyłączeniem jednak specjalnych środków wychowawczo-leczniczych z art. 12 u.p.n. Z kolei przepisy u.p.n. w stosunku do nieletnich już 
uzależnionych od alkoholu skutkują w tym względzie przede wszystkim możliwością stosowania przymusowego (niedobrowolnego) leczenia (art. 12).

Choć w świetle założeń ustawy z 1982 r. wystarczającą podstawą wszczęcia postępowania w sprawie nieletniego jest stwierdzenie samego powtarzalnego faktu używania alkoholu, bez konieczności stwierdzenia popełnienia (pod jego wpływem lub w związku z nim) czynu karalnego, to jednak należy zwrócić uwagę, że o ile używanie alkoholu nie stanowi naruszenia normy prawnej, to już pewne formy jego nielegalnego uzyskania (np. te wypełniające znamiona czynów z art. 119 k.w. czy art. $278 \S 1$ k.k. popełnionych między 13 a przed ukończeniem 17 roku życia) mogą stanowić czyny karalne w rozumieniu u.p.n. W konsekwencji początkowy sygnał o demoralizacji nieletniego uzależnionego od alkoholu czy też zagrożonego takim uzależnieniem doprowadzić może do przypisania mu czynu karalnego i związanej z tym konieczności wyboru przez sąd jednej tylko podstawy wszczęcia postępowania.

Ponadto ustawa o wychowaniu w trzeźwości i przeciwdziałaniu alkoholizmowi zakazuje „spożywania napojów alkoholowych m.in. w na terenie szkół, a także w miejscu publicznym, z wyjątkiem miejsc przeznaczonych do ich spożycia na miejscu, w punktach sprzedaży tych napojów” (art. 14; na temat pojęcia „miejsce publiczne" - zob. np. wyrok Trybunału Konstytucyjnego z dnia 21 września 2015 r., sygn. akt K 28/13, niepubl.). Jednakże zaliczenie na gruncie u.p.n. do czynów karalnych tylko wyliczonych wykroczeń z k.w. (nie zaś wykroczeń z ustaw szczególnych, w tym z u.w.t.p.a) powoduje, że dopuszczenie się przez nieletniego innego wykroczenia przewidzianego w tym kodeksie lub ustawie odrębnej stanowić może jedynie zachowanie świadczące o jego demoralizacji (Korcyl-Wolska, 2008, s. 60).

Skoro sam fakt, że nieletni jest uzależniony od alkoholu albo też osobą zagrożoną tym nałogiem ze względu na używanie alkoholu stanowi podstawę do wszczęcia postępowania w trybie u.p.n. (art. 21 w zw. z art. 2), to konsekwencją jego przeprowadzenia będzie rozważenie zastosowania środka/ów w niej przewidzianych. Głównym założeniem podjętych przez sąd rodzinny działań będzie więc szeroko rozumiane przeciwdziałanie demoralizacji nieletniego poprzez zastosowanie środków, wśród których szczególne miejsce zajmują środki wychowawczo-lecznicze. W tym kontekście w ramach u.p.n. wyróżnić można zasadniczo trzy grupy środków: 1) „zwykłe” środki wychowawcze, które mogą być stosowane zarówno wobec nieletnich uzależnionych od alkoholu, jak i nieletnich dopiero zagrożonych uzależnieniem ze względu na fakt używania alkoholu; 2) specjalne środki, które mogą być stosowane jedynie wobec nieletniego alkoholika (środki wychowawczo-lecznicze); 3) środki, których wykonanie - w związku z używaniem alkoholu przez nieletniego lub wykazywaniem cech uzależnienia alkoholowego - obciąża jego rodziców lub opiekuna.

Przykładowo do środków, które mogą znaleźć zastosowanie wobec nieletnich z problemem alkoholowym jak i nie-alkoholików, zaliczyć należy odpowiednio zobowiązanie nieletniego (na podstawie art. 6 pkt 2 u.p.n.) do zaniechania używania alkoholu w celu wprowadzenia się w stan odurzenia, zobowiązanie do uczestniczenia w odpowiednich zajęciach o charakterze terapeutycznym czy zobowiązanie do powstrzymania się od przebywania w określonych środowiskach lub 
miejscach (w domyśle - tych, w których np. dostęp do alkoholu jest ułatwiony). Ponadto na podstawie art. 6 pkt 6 u.p.n. sąd rodzinny może skierować nieletniego do ośrodka kuratorskiego, a także do organizacji społecznej lub instytucji zajmujących się pracą z nieletnimi o charakterze wychowawczym, terapeutycznym lub szkoleniowym, po uprzednim porozumieniu się z tą organizacją lub instytucją.

Z kolei środki stosowane wobec rodziców uzależnionego albo zagrożonego uzależnieniem alkoholowym nieletniego związane są nie mniej ważnym wątkiem poruszanym przez wspomnianą preambułę do u.p.n. - zagadnieniem umacniania funkcji opiekuńczo-wychowawczej i poczucia odpowiedzialności rodzin za wychowanie nieletnich na świadomych swych obowiązków członków społeczeństwa. Jak wskazuje V. Konarska-Wrzosek, sformułowanie tego celu opiera się na słusznym założeniu ustawodawcy, że to na rodzicach w pierwszej kolejności ciąży obowiązek prawidłowego wychowania własnych dzieci. Takie podejście do postępowania z nieletnimi jest z kolei pokłosiem zmian w postrzeganiu i ocenianiu nagannych zachowań nieletnich, które często są efektem nieprawidłowego wykonywania władzy rodzicielskiej i opieki nad dzieckiem. A contrario jeśli funkcja ta wykonywana jest w sposób właściwy, to stanowi najlepszy sposób przeciwdziałania procesowi demoralizacji młodego człowieka. Dla realizacji omawianego celu ustawa przewiduje szereg środków i sposobów, aby uaktywnić rodziców w pełnieniu przez nich funkcji opiekuńczo-wychowawczej wobec nieletnich, aby w konsekwencji udało się wychować ich na pełnowartościowych członków społeczeństwa (Konarska-Wrzosek, 2013, s. 64). Ustawa nie czyni przy tym rozróżnienia, czy podstawę owej aktywizacji rodziców lub opiekuna stanowi przejaw demoralizacji czy czyn karalny nieletniego. W przypadku nieletnich uzależnionych od alkoholu, jak i używających alkoholu, ustawodawca przewidział np. środek w postaci zobowiązania rodziców lub opiekuna do poprawy warunków wychowawczych, bytowych lub zdrowotnych nieletniego, a także do ścisłej współpracy ze szkołą (do której nieletni uczęszcza), poradnią psychologiczno-pedagogiczną lub inną poradnią specjalistyczną, zakładem pracy (w którym jest zatrudniony) oraz lekarzem lub zakładem leczniczym (art. 7 § 1 pkt 1 u.p.n.).

Wskazane środki nie znajdą jednak uzasadnienia w przypadku, gdy środowisko rodzinne nieletniego nie daje rękojmi należytego wykonywania władzy rodzicielskiej. Głęboka demoralizacja rodziców, nadużywanie przez nich alkoholu czy narkotyków stanowić powinno podstawę do decyzji sądu rodzinnego o zastosowaniu środka zmieniającego jego środowisko wychowawcze - np. umieszczenia w młodzieżowym ośrodku wychowawczym albo rodzinie zastępczej zawodowej, która ukończyła szkolenie przygotowujące do sprawowania opieki nad nieletnim (art. 6 pkt 9 u.p.n.). Celem tych środków jest oddziaływanie wychowawcze na nieletniego w specjalnie stworzonych warunkach oraz jego izolacja od destrukcyjnego wpływu dotychczasowego środowiska.

Wreszcie na koniec wspomnieć wypada o środkach wychowawczo-leczniczych, które mogą mieć zastosowanie jedynie wobec osoby uzależnionej od alkoholu (art. 6 pkt. 11 u.p.n. w zw. z art. 12 u.p.n.). Przed nowelą z 15 września 2000 r. środki te mogły być stosowane tylko wobec nieletnich, którzy byli sprawcami czynu karalnego, obecnie nie ma w tym względzie żadnych ograniczeń. Oznacza to, że wystarczającą podstawą ich orzeczenia jest stwierdzenie przejawu 
demoralizacji w postaci uzależnienia od alkoholu, bez konieczności stwierdzenia popełnienia (pod jego wpływem lub w związku z nim) czynu karalnego. Trzeba jednak podkreślić, że środki wychowawczo-lecznicze z u.p.n., podobnie jak środek poprawczy, obwarowane są wyraźnymi przesłankami ich stosowania. Jest to na gruncie omawianej ustawy sytuacja rzadka. Art. 12 u.p.n. obejmuje kilka przypadków. I tak jeśli stwierdzono u nieletniego upośledzenie umysłowe, chorobę psychiczną lub innego typu zakłócenia czynności psychicznych, bądź też nałogowe używanie alkoholu albo innych środków w celu wprowadzenia się w stan odurzenia - sąd rodzinny może orzec umieszczenie nieletniego w szpitalu psychiatrycznym lub innym odpowiednim zakładzie leczniczym. Jeśli natomiast zachodzi potrzeba zapewnienia takiemu nieletniemu tylko opieki wychowawczej - to sąd może orzec umieszczenie go w młodzieżowym ośrodku wychowawczym. Wreszcie jeśli nieletni jest upośledzony w stopniu głębokim i wymaga jedynie opieki (a nie leczenia i oddziaływań o charakterze wychowawczym) - sąd może orzec umieszczenie go w domu pomocy społecznej.

Co równie istotne, orzeczenie któregokolwiek z tych 3 środków wymaga zgodnie z art. 25 § 2 u.p.n. uzyskania uprzedniej specjalistycznej, kompleksowej diagnozy osobowości nieletniego oraz opinii w przedmiocie właściwych kierunków oddziaływania na nieletniego. O ile jednak zasięgnięcie opinii na temat diagnozy osobowości nieletniego jest obligatoryjne, o tyle ustawodawca pozostawił sądowi rodzinnemu dać pewną swobodę co do wyboru podmiotu mającego ją sporządzić. Co do zasady więc opinię taką winien wydać opiniodawczy zespół sądowych specjalistów. Sąd może jednak zwrócić się o wydanie opinii także do innej specjalistycznej placówki lub biegłego albo biegłych. Tylko w jednym przypadku dopuszczalne jest również pominięcie wymogu zasięgnięcia takiej opinii, mianowicie jeżeli sąd dysponuje opinią o nieletnim sporządzoną w innej sprawie w okresie 6 miesięcy poprzedzających wszczęcie postępowania. Wtedy zgodnie z $\S 4$ art. 25 u.p.n. może wykorzystać ją w „swoim” postępowaniu.

Opinię wydaną na podstawie art. 25 § 1 u.p.n. należy jednak odróżnić od opinii o stanie zdrowia psychicznego nieletniego (art. 25a u.p.n.). Ta ostatnia wchodzi w grę wówczas, gdy zajdzie potrzeba oceny stanu psychicznego nieletniego, a więc w przypadkach, gdy pojawią się uzasadnione wątpliwości w tym zakresie. Taką opinię w formie postanowienia zarządzenie sądu rodzinnego sporządzają po badaniu nieletniego co najmniej dwaj biegli lekarze psychiatrzy. Dopiero na ich wniosek do udziału w wydaniu opinii sąd może powołać także biegłych innych specjalności. W razie zgłoszenia przez biegłych takiej konieczności badanie stanu zdrowia psychicznego nieletniego może być również połączone z obserwacją w podmiocie leczniczym niebędącym przedsiębiorcą (art. 25a § 2-4 u.p.n.) (szerzej na ten temat np. Eichstaedt, 2017, s. 378-383).

Umieszczenie nieletniego w szpitalu psychiatrycznym lub innym odpowiednim zakładzie leczniczym m.in. w sytuacji, gdy nieletni jest uzależniony od alkoholu, ma na celu jego uprzednie wyleczenie, aby dopiero w dalszej kolejności można było poddać go oddziaływaniom wychowawczym. To oznacza w praktyce, że leczenie uzależnienia od alkoholu albo będzie poprzedzać oddziaływania o charakterze wychowawczym albo będzie prowadzone równolegle. W przeciwnym razie bez takiej terapii oddziaływania wychowawcze będą po prostu 
nieskuteczne (Konarska-Wrzosek, 2013, s. 100). Kwestie szczegółowe związane z kierowaniem, przyjmowaniem, przenoszeniem, zwalnianiem i pobytem nieletnich w takich placówkach leczniczych reguluje rozporządzenie Ministra Zdrowia z dnia 20 kwietnia 2005 r. (Dz.U. z 2005 r. Nr 79, poz. 692 ze zm.). Wynika z niego m.in., że nieletniego uzależnionego od alkoholu kieruje się do publicznego zakładu leczenia (lecznictwa) odwykowego dysponującego warunkami wzmocnionego zabezpieczenia ( 33 ust. 2 w zw. z $\S 2$ ust. 1 pkt 2), albo innego podmiotu leczniczego niebędącego przedsiębiorcą, sprawującego opiekę medyczną m.in. nad osobami uzależnionymi od alkoholu albo substancji psychoaktywnych (§ 2 ust. 1 pkt 3). Do takiego zakładu sąd rodzinny przesyła odpis prawomocnego postanowienia o zastosowaniu środka leczniczego wraz z opinią wydaną $w$ trybie art. 25 lub 25a u.p.n. Przed umieszczeniem nieletniego w zakładzie lecznictwa odwykowego sąd może zwrócić się do Instytutu Psychiatrii i Neurologii w Warszawie o wskazanie w terminie 14 dni od otrzymania stosownej dokumentacji właściwego zakładu (§ 6 ust. 1; $\S 6$ ust. 3 w zw. z ust. 1). Jeśli nie skorzysta z tej możliwości, to zgodnie z ogólnymi zasadami będzie to zakład właściwy ze względu na miejsce zamieszkania lub pobytu nieletniego (ustalanych na podstawie art. 25-28 ustawy z dnia 23 kwietnia 1964 r. - Kodeks cywilny, Dz.U. 1964 r. Nr 16, poz. 93 ze zm.), a gdy jest to niemożliwe - zakład położony najbliżej jednego z tych miejsc, z uwzględnieniem obszaru działania danej placówki (§ 2 ust. 3). Natomiast jeśli to Instytut decyduje o miejscu umieszczenia nieletniego, to ma obowiązek uwzględnić w szczególności takie okoliczności jak: rodzaj czynów zabronionych, których dopuścił się nieletni w przeszłości, rodzaj, częstość i skutki zachowań agresywnych lub ucieczkowych w przeszłości, aktualny stan jego zdrowia (w tym stan psychiczny i somatyczny), uzależnienie od alkoholu, związek miedzy zaburzeniami psychicznymi a zachowaniami niebezpiecznymi, ogólną sprawność fizyczną, szczególne wskazania do postępowania leczniczego i rehabilitacyjnego, przebieg oraz wyniki dotychczasowego leczenia i rehabilitacji (§ 5).

Po przewiezieniu do zakładu, w którym ma być wykonywany środek leczniczy, nieletniego uzależnionego od alkoholu zapoznaje się z zakresem jego praw i obowiązków. Ponadto przy przyjęciu nieletni poddawany jest badaniu psychiatrycznemu, internistycznemu i neurologicznemu (§ 7, 8 pkt 3, 9). W razie stwierdzenia u przyjmowanego (albo już przebywającego w zakładzie) nieletniego zaburzeń pourazowych, powypadkowych lub innych chorób lekarz kieruje nieletniego niezwłocznie do innego odpowiedniego podmiotu leczniczego (§ 10 ust. 1 w zW. z § 2 ust. 1 pkt 4). O konieczności takiego przeniesienia nieletniego zawiadamia się m.in. sąd rodzinny (§ 10 ust. 2). Ponadto zawsze w ramach postępowania leczniczego lub rehabilitacyjnego jest możliwe przenoszenie nieletniego na podstawie orzeczenia sądu, ale na wniosek uprawnionego podmiotu, do innego zakładu dysponującego odpowiednimi zabezpieczeniami oraz odpowiednimi możliwościami leczniczymi i rehabilitacyjnymi (szerzej § 11 ust. 2-3, § 12-14).

Jeśli nieletni znajdzie się w odpowiednim zakładzie, zostaje objęty zaplanowanym i zindywidualizowanym postępowaniem leczniczym, rehabilitacyjnym, którego celem jest poprawa jego stanu zdrowia i zachowania w takim stopniu, który umożliwi mu powrót do życia w społeczeństwie oraz kontynuowania leczenia już poza zakładem (§ 18). W przypadku nieletniego uzależnionego od alkoholu 
zindywidualizowane postępowanie diagnostyczne, lecznicze i rehabilitacyjne obejmuje w szczególności: 1) diagnostykę zaburzeń psychicznych i zaburzeń zachowania związanych z używaniem alkoholu; 2) leczenie szkód zdrowotnych spowodowanych używaniem alkoholu; 3) indywidualną i grupową psychoterapię osób uzależnionych oraz 4) działania konsultacyjno-edukacyjne dla osób uzależnionych i ich rodzin (§ 19 ust. 2). Wobec wszystkich nieletnich przebywających na leczeniu w zakładzie leczniczym realizowany jest również obowiązek szkolny (§ 19 ust. 3).

Zakład leczniczy, w którym nieletni przebywa, ma obowiązek informowania sądu rodzinnego minimum raz na 6 miesięcy o stanie zdrowia nieletniego i postępach w leczeniu oraz rehabilitacji. Jeśli natomiast ustała przyczyna, dla której nieletni został skierowany do takiego zakładu (np. zakończył z powodzeniem terapię odwykową), to zakład musi niezwłocznie powiadomić sąd o ustaniu tej przyczyny (§ 15 ust. 1). Podkreślić też należy, że pobyt nieletniego w zakładzie dysponującym warunkami wzmocnionego zabezpieczenia nie powinien trwać dłużej, niż jest to konieczne dla bezpieczeństwa nieletniego i jego otoczenia (§ 22). Zwolnienie z zakładu następuje na podstawie prawomocnego postanowienia sądu rodzinnego (ustanie przyczyny), chyba że wykonywanie środka leczniczego ustaje z mocy prawa (§ 15 ust. 3) - czyli wraz z ukończeniem przez nieletniego 18 roku życia (art. $73 \S 1$ u.p.n.).

\section{Podsumowanie}

Pozostaje na zakończenie wrócić do postawionego na początku pytania o miejsce środków przewidzianych na gruncie polskiego postępowania z nieletnimi w systemie wsparcia społecznego i pomocy osobom z problemem alkoholowym. Wydaje się, że ustawa z 1982 r. tworzy wartościową podstawę rozsądnego decydowania o sprawach nieletnich, także w omawianym kontekście uzależnienia dziecka od alkoholu. Poprzez „nasycenie” jej rozwiązań elementami socjopedagogicznymi, z jednej strony uwagę sądu rodzinnego, a także innych podmiotów zaangażowanych w przebieg postępowania, słusznie kieruje się na problemy osobowości nieletniego, jego środowisko i potrzeby wychowawcze. Z drugiej strony istotne jest zachowanie właściwej równowagi między autonomicznymi interesami nieletniego (jego dobrem), a interesami ogółu w postaci woli dopasowania jego zachowania do wymagań i potrzeb społecznych, a tym samym znalezienie pewnej harmonii między pokusą nadmiernego oddziaływania prewencyjno-wychowawczego a całkowitą rezygnacją ze stosowania wychowania opiekuńczego. Jest to szczególnie dobrze widoczne np. w kontekście wspomnianego poszanowania autonomii uzależnionego od alkoholu nieletniego, który może zrealizować swoje prawo do dobrowolnego leczenia. Stąd też nawet zaistnienie określonych w art. 12 u.p.n. podstaw do orzeczenia środków leczniczo-wychowawczych wobec nieletniego alkoholika nie obliguje, a jedynie daje sądowi rodzinnemu wybór jednego z nich i to odpowiednio dostosowanego do indywidualnych potrzeb nieletniego. Biorąc pod uwagę fakt, że wychowanie jest procesem elastycznym, w którym niejednokrotnie 
wymaga się reakcji natychmiastowych na zmieniająca się sytuację, ustawodawca pozwala również na dostosowywanie podjętych decyzji do zaistniałych okoliczności. Przykładowo, jeśli uzależniony od alkoholu nieletni nie daje już żadnej gwarancji ani poprawy zachowania bez leczenia uzależnienia ani też skutecznego leczenia w warunkach ambulatoryjnych, to sąd może na każdym etapie postępowania uznać, iż bezwzględnie wymaga on leczenia w warunkach stacjonarnych. Jest to bowiem dla niego jedyna szansa nie tylko na wyjście z nałogu, ale też na powstrzymanie postępującego w szybkim tempie procesu demoralizacji. Tym samym jedynie np. zakład leczniczy o wzmocnionym zabezpieczeniu jest w stanie w konkretnym przypadku zagwarantować efektywną terapię. Nie umniejszając zatem roli innych instrumentów prawnych w systemie wsparcia społecznego i pomocy osobom z problemem alkoholowym, należy pozytywnie ocenić rozwiązania prawne w zakresie przeciwdziałania alkoholizmowi nieletnich na gruncie u.p.n.

\section{Bibliografia}

Bartosik A. (red.) (2003), Alkohol i młodzież, Państwowa Agencja Rozwiązywania Problemów Alkoholowych, Warszawa.

Biernat R. (2015), Zachowania dewiacyjne młodzieży w kontekście dysfunkcji i patologii życia rodzinnego, „Społeczeństwo. Edukacja. Język” 3, s. 15-34.

Bojarski T., Skrętowicz E. (2007), Ustawa o postępowaniu w sprawach nieletnich. Komentarz, LexisNexis, Warszawa.

Cierpiałkowska L., Grzegorzewska I. (2016), Dzieci alkoholików w perspektywie rozwojowej i klinicznej, Wydawnictwo Naukowe UAM, Poznań.

Ciosek M. (2011), Sekretny świat rodziny z problemem alkoholowym, „Studia Gdańskie. Wizje i rzeczywistość" 8, s. 270-282.

Eichstaedt K. (2017), Opinia ambulatoryjna o stanie zdrowia psychicznego nieletniego, [w:] K. Eichstaedt, P. Gałecki, A. Depko (red.), Metodyka pracy biegłego psychiatry, psychologa oraz seksuologa w sprawach karnych, nieletnich oraz wykroczeń, Wolters Kluwer, Warszawa, s. 377-378.

Fiutak A. (2016), Odpowiedzialność karna za wykonanie zabiegu leczniczego bez zgody pacjenta, Wolters Kluwer, Warszawa.

Górecki P., Stachowiak S. (2010), Ustawa o postępowaniu w sprawach nieletnich. Komentarz, Wolters Kluwer, Warszawa.

Grzegorczyk T. (1988), Sytuacja nieletniego w postępowaniu w sprawach nieletnich, „Nowe Prawo” 1, s. 14-15.

Grześkowiak A. (1984), Reforma postępowania z nieletnimi, „Studia Prawnicze” 1-2, s. 43.

Heath A.C. i in. (1998), Genetic and environmental contributions to alcohol dependence risk in a national twin sample: Consistency of findings in women and men, „Psychological Medicine” 27, s. 1381-1396.

Jaworska-Dębska B. (1995), Spór wokół modelu polskiej regulacji alkoholowej. Zagadnienia administracyjnoprawne, Wydawnictwo Uniwersytetu Łódzkiego, Łódź.

Kalinowski S. (2010), Przejawy wykluczenia społecznego, „e-Liberté” 17, dostępne online: https:// liberte.pl/przejawy-wykluczenia-spolecznego (data dostępu: 20.01.2020).

Klaus W. (2009), Dziecko przed sądem. Wymiar sprawiedliwości wobec przestępczości młodszych nieletnich, Wydawnictwa Akademickie i Profesjonalne, Warszawa.

Konarska-Wrzosek V. (2013), Prawny system postępowania z nieletnimi w Polsce, Wolters Kluwer, Warszawa.

Korcyl-Wolska M. (2008), Postępowanie w sprawach nieletnich, Wolters Kluwer, Warszawa.

Łakoma S. (2004), Pojęcie, priorytet i treść dobra dziecka, „Studia Prawno-Ekonomiczne” 69, s. $87-110$. 
Marek A. (2007-2008), Uwagi o reformie prawa dotyczącego nieletnich, „Archiwum Kryminologii” 29-30, s. 383-391.

Muszyńska A. (2004), Narkomani. Sprawcy czynów karalnych, Zakamycze, Kraków.

Safjan M. (1994), Standardy prawne Rady Europy. Teksty i komentarze, t. I, Oficyna Naukowa, Warszawa.

Samochowiec J., Fiszer-Piosik E., Horodnicki J. (1998), Uwarunkowania genetyczne alkoholizmu, „Alkoholizm i Narkomania” 2, s. 179-192.

Siellawa-Kolbowska K. (2000), Recenzje: B. Fatyga, J. Sierosławski, A. Zieliński, P. Zieliński, Alkohol a młode pokolenie Polaków połowy lat dziewięćdziesiątych, „Alkoholizm i Narkomania” 13(2), s. 307-313.

Sienkiewicz Z. (1986), Kontrowersje dotyczące przesłanek umieszczenia nieletniego w zakładzie poprawczym, „Palestra” 3, s. 17-24.

Strzembosz A. (1983), Nowa ustawa o postępowaniu w sprawach nieletnich. Próba komentarza, Wydawnictwo Prawnicze, Warszawa.

Sztander W. (1993), Rodzina z problemem alkoholowym, Instytut Psychologii Zdrowia i Trzeźwości, Warszawa.

Wilkowska-Płóciennik A. (2011), Postępowanie w sprawach nieletnich, C.H. BECK, Warszawa.

Projekt ustawy o postępowaniu w sprawach nieletnich (1982), Warszawa.

Rozporządzenie Ministra Zdrowia z dnia 20 kwietnia 2005 r. w sprawie szczegółowych zasad kierowania, przyjmowania, przenoszenia, zwalniania i pobytu nieletnich w publicznych zakładach opieki zdrowotnej, Dz.U. z 2005 r. Nr 79, poz. 692 ze zm.

Ustawa z dnia 23 kwietnia 1964 r. - Kodeks cywilny, Dz.U. z 1964 r. Nr 16, poz. 93 ze zm.

Ustawa z dnia 26 października 1982 r. o postępowaniu w sprawach nieletnich, Dz.U z 1982 r. Nr 35, poz. 228 ze zm.

Ustawa z dnia 26 października 1982 r. o wychowaniu w trzeźwości i przeciwdziałaniu alkoholizmowi, Dz.U. z 1982 r. Nr 35, poz. 230 ze zm.

Ustawa z dnia 2 kwietnia 1997 r. - Konstytucja Rzeczypospolitej Polskiej, Dz.U. Nr 78, poz. 483 ze zm. Ustawa z dnia 6 czerwca 1997 r. - Kodeks karny, Dz.U. z 1997 r. Nr 88, poz. 553 ze zm.

Ustawa z dnia 6 czerwca 1997 r. - Kodeks karny wykonawczy, Dz.U. z 1997 r. Nr 90, poz. 557 ze zm. Wyrok Sądu Apelacyjnego w Katowicach z dnia 18 marca 2004, sygn. akt II Aka 531/03, LEX nr 142829. Wyrok Trybunału Konstytucyjnego z dnia 21 września 2015 r., sygn. akt K 28/13, niepubl.

\section{Abstract}

Alcohol abuse results in a million deaths every year, a significant proportion of which are young people. Moreover, a wide variety of alcohol-related problems can have a devastating impact not only on minors but also on their families, and can seriously affect community life. The occurrence of problems associated with alcohol abuse contributed to a number of strategies aimed at their prevention or partial reduction. The purpose of the article is to present selected actions taken in this scope by juvenile courts, based on the Act of 26th October 1982 on proceedings in juvenile cases. The fact that the Polish system of dealing with young offenders is based on the care-education-protection system, and that the young people's best interests are recognized as its leading directive, means abandoning repression as the primary measure used against juveniles, and referring to the principle of children's welfare. This priority of the welfare of juveniles, which has been recognized as a fundamental directive of the Polish model of dealing with them, should theoretically impact all legal solutions adopted within the directive and the decisions taken at every stage. Those that would not prove favourable to the welfare of juveniles (which is defined as the intention to achieve such beneficial changes in his or her personality and behavior so that he or she could properly function in the social reality, in accordance with his or her biological age and maturity) are fundamentally wrong and should be changed or repealed. This also refers to special legal measures, which are supposed to prevent alcohol addiction among minors.

Keywords: juvenile, addiction, alcohol, demoralization, preventive measures 